Proceedings of the 32nd Annual Meeting of the Brazilian Embryo Technology Society (SBTE); Florianopólis, SC, Brazil, August 16th to 18th, 2018.

\title{
The local regulation of folliculogenesis by members of the transforming growth factor superfamily and its relevance for advanced breeding programmes
}

\author{
Jennifer L. Juengel ${ }^{1}$, Peter R. Smith, Laurel D. Quirke, Michelle C. French, Sara J. Edwards \\ Reproduction, Animal Science, AgResearch Ltd., Invermay Agricultural Centre, Mosgiel New Zealand.
}

\begin{abstract}
Regulation of the growth and maturation of the ovarian follicle is critical for normal reproductive function. Alterations in this growth can lead to pathological conditions, such as cystic follicles, reduced oocyte quality, or an abnormal endocrine environment leading to poor fertility. Alterations in follicular growth also influence the number of follicles ovulating and thus can change litter size. Both endocrine factors, such as follicle stimulating hormone and luteinizing hormone, as well as local factors, are known to regulate follicular growth and development. This review will focus on the role of local factors in regulation of ovarian follicular growth in ruminants, with a focus on members of the transforming growth factor superfamily. The potential role of these factors in regulating proliferation, apoptosis, steroidogenesis and responsiveness to gonadotrophins will be considered.
\end{abstract}

Keywords: granulosa cells, oocyte, theca cells.

\section{Introduction}

At formation, the ovarian follicle consists of the female germ cell, the oocyte, surrounded by a single layer of support cells, the granulosa cells. Once follicular growth has been initiated, follicular development can be characterised through proliferation of the granulosa and recruitment and proliferation of additional support cells (theca cells). The oocyte continues to grow and mature, and the granulosa and theca cells differentiate to be able to communicate with the hypothalamus, pituitary and reproductive tract and respond to endocrine factors controlling ovulation, final maturation of the oocyte, and luteinisation for subsequent progesterone production for maintenance of early pregnancy. Another important aspect of this development is factors controlling atresia of the ovarian follicle, as the majority of ovarian follicles follow this pathway rather than the pathway to ovulation. It is known that follicles at any developmental stage can become atretic, from a primordial follicle right through to a follicle that had developed to a preovulatory size but failed to ovulate and regressed (Matsuda et al., 2012). However, it is also clear that while fewer follicles are classified as atretic during preantral follicular development, many follicles become atretic around or shortly after the time of formation of the antrum (Driancourt et al., 1985).

A large proportion of follicular development can occur without pituitary hormones. For instance in sheep, follicles will grow to approximately $3 \mathrm{~mm}$ in diameter after the pituitary has been removed (McNatty et al., 1990). Once a follicle has reached $3 \mathrm{~mm}$ in diameter, the remaining growth to obtain a preovulatory size (approximately 5-6 $\mathrm{mm}$ ) can occur in a matter a days. Considering that normal development of a follicle to ovulation has been estimated to take six months, clearly the majority of follicular growth is independent of gonadotrophins. Similar results are observed in cattle, with $\mathrm{LH}$ only required once a follicle reaches a diameter of $8-9 \mathrm{~mm}$ and FSH likely required for follicles over 4 $\mathrm{mm}$ (Mihm and Bleach, 2003). Ovulation occurs in bovine follicles around $15 \mathrm{~mm}$ in diameter although this varies with age and breed (Pohler et al., 2012). It should be noted however, that while the earlier stages of follicular development are not dependent on the gonadotrophins, these small growing follicles are responsive to both FSH and $\mathrm{LH}$. Receptors (R) for FSH are expressed in the granulosa cells starting during preantral development and LHR are present on theca cells starting in late preantral/early antral follicles (Tisdall et al., 1995; Bao and Garverick, 1998; Logan et al., 2002; Saraiva et al., 2011; Barros et al., 2013).

Multiple locally produced factors have been identified as controlling the development of the ovarian follicle. These locally produced factors (Fig. 1) include, but are not limited to, members of the transforming growth factor beta (TGFB) super family, insulin-like growth factors (IGF), fibroblast growth factors (FGF), platelet derived growth factors (PDGF) and KIT ligand (KITL). Additionally, the TGFB superfamily consists of multiple sub-families, including the growth and differentiation factors (GDF), bone morphogenetic proteins (BMP), activins and inhibin, TGFB and antimullerian hormone (AMH). In this review we will focus on members of the GDF, BMP and TGFB sub-groups of the TGFB superfamily. Readers are directed to additional reviews for information on other factors controlling ovarian follicular development (Young and McNeilly, 2010; Buratini and Price, 2011; Scaramuzzi et al., 2011; Knight et al., 2012; Campbell et al., 2014; Knight and Glister, 2014; Monniaux et al., 2014; Price, 2016; Shimizu, 2016; Silva et al., 2016; Pankhurst, 2017; Estienne and Price, 2018) 
$E R B(\mathrm{gc} \& \mathrm{Ooc}), B M P R 2$ (ooc \& gc), BMPR1B (ooc \& gc), PDGFRA (gc), $P D G F R B(\mathrm{gc}), T G F B R 1$ (ooc \& gc)

FSHR (gc), FGFR (gc), ACTR2B (gc), AMHR2 (gc)
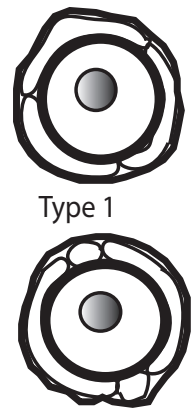

Type 1a

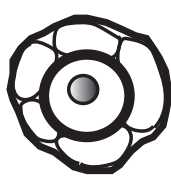

Type 2

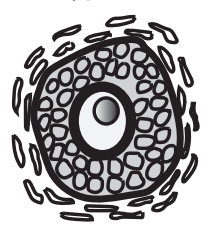

Small Preantral

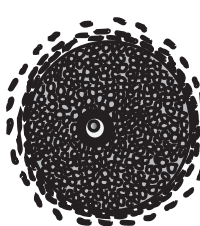

Large Preantral

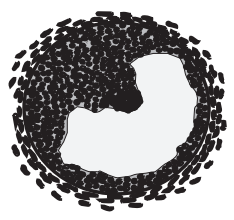

Small Antral

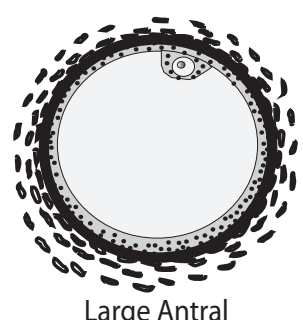

$E G F R$ (gc \& th), LEPRB (gc, th \& Ooc), LHR (th)

LHR (gc dominant follicle)

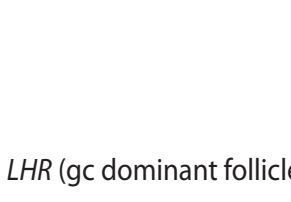

ERA (gc), TGFBR2 (th)

Large Antral
GDF9 (ooc), KITLG (gc), KIT (ooc), WT-1 (gc),

BMP15 (ooc), BMP2* $4^{*}, 7^{*}$ (gc)

BMP 6 (ooc \& gc*), FGF10 (ooc \& th)

$\operatorname{INHBB}(\mathrm{gc}), \operatorname{VEGF}(\mathrm{gc})$

$A M H(g c), F S T$ (gc), BMP2*, 4*, 6* (gc), BMP15 (ooc), bFGF (gc), PDGFA (ooc \& gc)

INHA (gc), FST (gc), TGFB1 (th),

TGFB1*,2*, $3^{*}$ (ooc, gc \& th), BMP2*, 4*, 6*, $7^{*}$ (th)
CYP11A1 (th \& gc), CYP17A1 (th), IGF1 (gc \& th), PDGFA (gc), PDGFB (gc \& th), PDGFC (gc \& th), $H S D 3 B$ (th)

NHBA (gc), LEP (gc, th \& ooc) IGF1 (gc, th), FGF7 (th), BMP7*(gc)

CYP19A1 (gc),

CARTPT (gc \& low in ooc)

Figure 1. The stages of follicular development and initiation of expression of selected proteins in the healthy follicle. Newly formed follicles can consist of either an oocyte surrounded by a single layer of granulosa cells with a flattened morphology (termed a type 1 or primordial follicle) or an oocyte surrounded by a single layer of granulosa cells with a mixture of flattened and cuboidal granulosa cells (termed a type 1a or transitional follicle; Juengel and Smith, 2014). The granulosa cells and the oocyte are isolated within a basement membrane and thus separated from the ovarian vasculature. Soon after follicles are formed, they begin to grow, forming a type 2 or primary follicle, which contain a single layer of cuboidal granulosa cells (Lundy et al., 1999). Type 3 or small preantral contains 2 to $<4$ complete layers of granulosa cells whereas a type 4 or large preantral follicle contains at least 4 complete layers of granulosa cells but no antral cavity is yet present. The theca can first be observed in some type 2 follicles and becomes very prominent in type 4 follicles (Lundy et al., 1999). These theca cells are located outside the basement membrane of the ovarian follicle and contain a rich blood supply. Patterns of expression are based on mRNA or protein localisation in either sheep, cattle or goat ovaries. Once expression is initiated, it is also observed in subsequent stages of development although concentrations may vary. ooc $=$ oocyte, $g c=$ granulosa cell, th $=$ theca. An asterisk $(*)$ indicates known differences in expression patterns between species with expression in sheep tending to be more restricted than that observed in cattle and goats. Please see text for more details. Information on expression of proteins was gathered from multiple references (Bezard et al., 1987; Wandji et al., 1992; Braw-Tal, 1994; Tisdall et al., 1994, 1995, 1997; Leeuwenberg et al., 1995; Xu et al., 1995; Logan et al., 2002, 2003; Juengel et al., 2004a, 2006a, b; Kobayashi et al., 2004; Buratini et al., 2007; Feary et al., 2007; Brito et al., 2012; Lima et al., 2012; Smith, 2012; Batista et al., 2013; Hao et al., 2014; Diaz et al., 2016). 


\section{The effects of TGFB superfamily members on granulosa cell proliferation and health (Fig. 2)}

Two oocyte-secreted growth factors from the TGFB superfamily, GDF9 and BMP15, are known to be essential for normal granulosa cell proliferation. In ewes homozygous for inactivating mutations in either growth factor, normal follicular development does not occur, and follicles are blocked in the early preantral stages of development (Davis et al., 1992; Braw-Tal et al., 1993; Galloway et al., 2000; Nicol et al., 2009). Immunisation against GDF9 or BMP15 can also affect follicular development in both sheep and cattle, resulting in reduced numbers of antral follicles which were smaller in size (Juengel et al., 2002, 2009, 2011). Treatment of granulosa cells from small antral follicles, primarily prior to gonadotrophin dependence (i.e. from follicles 1$2 \mathrm{~mm}$ in sheep and 1-4.5 $\mathrm{mm}$ in cattle) with ovine (o) BMP15 or the combination of oBMP15 and oGDF9 induced thymidine incorporation indicative of proliferation (McNatty et al., 2005).

Other BMPs and GDFs are also produced by the ovarian follicles, although their role in regulating local follicular development is less clear and may vary between species. The oocyte also produces BMP6 in sheep (Juengel et al., 2006b) and cattle (Hussein et al., 2005) but BMP6 did not induce cell proliferation in sheep (Juengel et al., 2006b) and had a small effect on bovine mural granulosa cells (Glister et al., 2004) and no effect on cumulus cells (Gilchrist et al., 2006). In cattle, granulosa and theca cells from small antral follicles (1-4 mm in diameter) produce BMP2, BMP4, BMP6 and BMP7 (Glister et al., 2010) whereas in sheep, as determined by in situ hybridisation, only granulosa cells of atretic follicles express BMP2. The other BMPs were not expressed by the granulosa or theca cells, although BMP4 was produced in ovarian stroma cells surrounding some follicles. In sheep, none of these growth factors stimulated proliferation of the granulosa cells (Souza et al., 2002; Campbell et al., 2006; Juengel et al., 2006b) although one study showed a small stimulation of proliferation when examining BMP4 (Fabre et al., 2003). In cattle neither BMP2 nor 4 affected cell proliferation (Glister et al., 2004; Selvaraju et al., 2013), with BMP6 and 7 promoting a small increase in viable granulosa cell numbers (Glister et al., 2004). The effects of GDF5 on granulosa cell proliferation has been examined with no effect observed (Fabre et al., 2003).

In sheep, TGFB1 and TGFB2, but not TGFB3, are produced by ovarian follicles, in the theca cells of type 3 and larger follicles (Juengel et al., 2004a). In cattle, TGFB1, 2 and 3 were all detected in oocytes, granulosa and theca cells, with TGFB3 being the most strongly expressed (Nilsson et al., 2003). TGFB1 has also been detected in oocytes of goat preantral follicles (Rodrigues et al., 2014). TGFB1 and 2 both reduced numbers of granulosa cells after culture in sheep (Juengel et al., 2004a), although no effect of TGFB1 on proliferation was observed (TGFB2 was not tested). In cattle, the effects of TGFB are inconsistent, with TGFB2 having a mild stimulatory effect on proliferation (Gilchrist et al., 2003), and TGFB (type unspecified) having no effect on unstimulated, or an inhibitory effect on epidermal growth factor (EGF)-stimulated, proliferation (Skinner et al., 1987).

Members of the BMP family, including BMP4, 6, 7 and 15 have been linked to reduced cumulus/mural granulosa cell apoptosis in cattle (Hussein et al., 2005; Kayamori et al., 2009). In bovine granulosa cells, BMP4 suppression of apoptosis was linked to the PI3K/PDK-1/Akt pathway whereas BMP7 suppression of apoptosis was linked to the PI3K/PDK-1/PKC pathway (Shimizu et al., 2012). In bovine preantral follicles, culture with BMP15 alone stimulated follicle growth without reducing viability whereas culture with the combination of FSH and BMP15 resulted in reduced numbers of viable follicles, potentially linked to over stimulation of proliferation of granulosa cells (Passos et al., 2013). In contrast, GDF9 had no effect on apoptosis in cattle cumulus cells (Hussein et al., 2005). Further evidence for the role of members of the BMP superfamily in regulating apoptosis is provided by the observation that overexpression of the regulatory micro(mi)RNA-375 decreases expression of BMPR2 and increases apoptosis of bovine cumulus cells (Chen et al., 2017). This receptor is key for the actions of many BMPs including the synergistic actions of BMP15 and GDF9 (Edwards et al., 2008). Additionally, reduction of SMAD2 expression, through either chimiRNA-4110 mimics or SMAD2 interference, reduced SMAD2 mRNA and protein in caprine granulosa cells and increased apoptosis (An et al., 2017). The SMAD2/3 pathway is important for the synergistic actions of ovine BMP15 and GDF9 (Reader et al., 2011). In contrast to the suppressive effects of some BMP family members on apoptosis, members of the TGFB subfamily may actually induce apoptosis in ruminants. As indicated before, treatment with TGFB1 or 2 reduced DNA content after culture in sheep granulosa cells (Juengel et al., 2004a), and TGFB1 increases apoptosis in cattle granulosa cells (Zheng et al., 2009).

\section{The effects of TGFB superfamily members on theca cell proliferation and health (Fig. 2)}

Less is known regarding regulation of theca cell function. As indicated previously, the theca cells express many members of the TGFB superfamily and their receptors in sheep, cattle and goats (Glister et al., 2004, 2010; Juengel et al., 2004a, 2006b; Feary et al., 2007; Costa et al., 2012; Lima et al., 2012; Rodrigues et al., 2014). BMP2, 4 and 6 stimulated theca cell proliferation in sheep, with the effects of BMP7 not tested (Campbell et al., 2006). In cattle, BMP4, 6 and 7 stimulated theca cell proliferation in the presence or absence of LH, while BMP2 was not tested (Glister et al., 2005). GDF9 stimulates proliferation of theca cell isolated from small, but not larger, antral follicles (Spicer et al., 2008). 


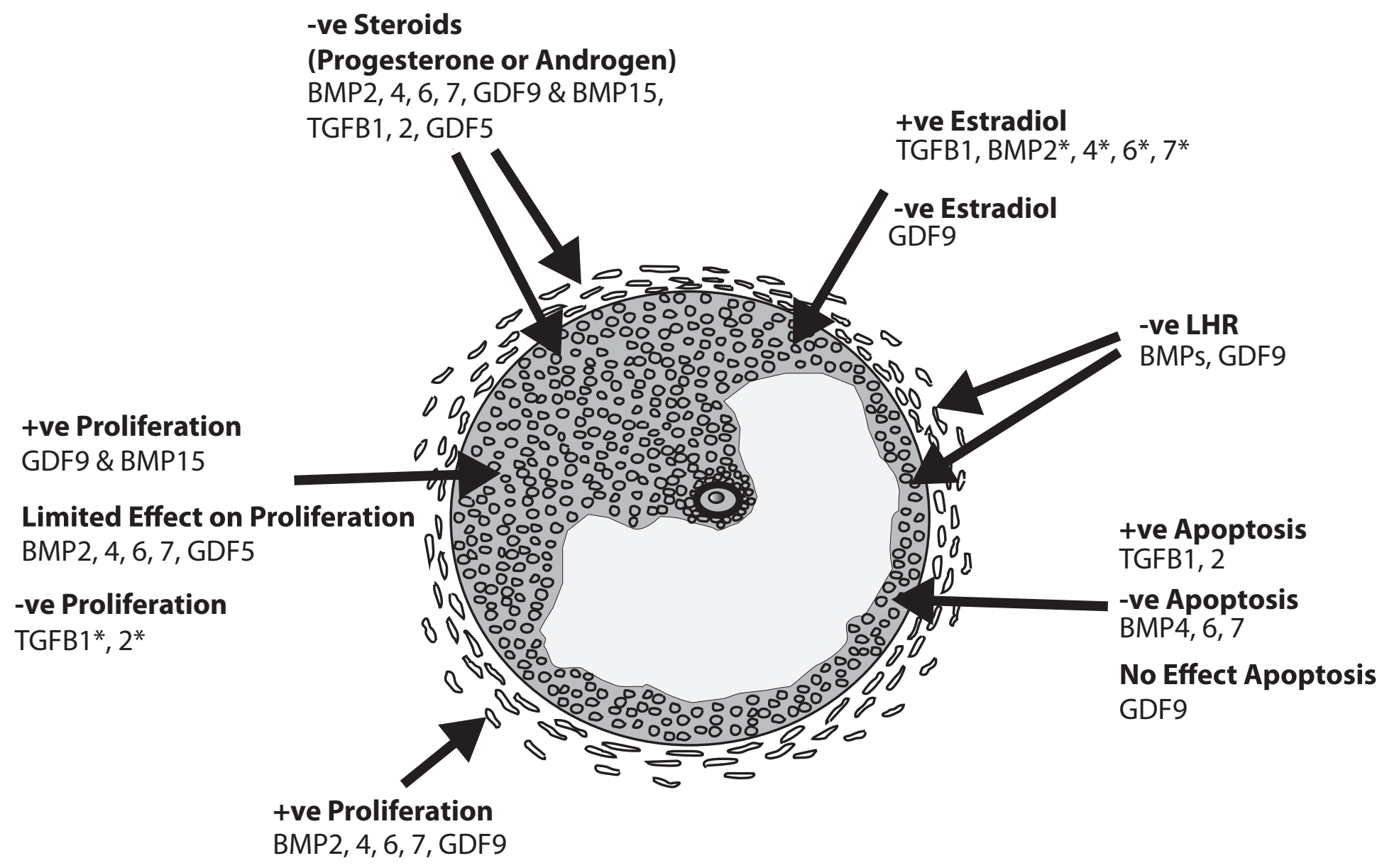

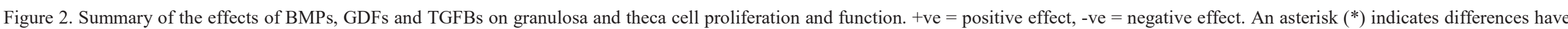
been observed in responses between species (sheep vs. cattle) or studies within species. Please see text for more details. 


\section{TGFB superfamily regulation of granulosa and theca cell function (Fig. 2)}

One of the mechanisms that many of the locally produced growth factors use to alter ovarian follicular development during antral development is through regulating the follicle's ability to communicate with the hypothalamus and pituitary. In particular, regulation of steroids and inhibin A produced by the ovarian follicle, and receptors for the gonadotrophins, appear to be key mechanisms by which local factors affect the development of the ovarian follicle and, ultimately, the number of follicles available for ovulation. To this end, many of the local growth factors alter steroid synthesis and gonadotrophin responsiveness (Fig. 2).

\section{Regulation of steroidogenesis}

In ewes with reduced BMP15 function (i.e. those heterozygous for an inactivating mutation in BMP15 such as Inverdale) or altered BMP signalling (i.e. those heterozygous or homozygous for a mutation in $B M P R 1 B$, that is the Booroola mutation), a key feature is that oestrogen active follicles are observed at smaller sizes. Additionally, BMP4, 6 and 7 suppress basal and LH-stimulated androgen production from bovine theca cells (Glister et al., 2005). Suppression of expression of genes involved in steroidogenesis such as CYP17A1 (strongly suppressed), STAR, CYP11A1 and HSD3B1 mRNA were observed. This is consistent with the BMP family members suppressing steroidogenesis through downregulation of proteins important for steroid production. GDF9 also reduced both progesterone and androstenedione production from bovine theca cells (Spicer et al., 2008). Decreased expression of mRNA encoding LHCGR and CYP11A1 was observed following GDF9 treatment, but no effects on STAR or CYP17A1 mRNA were observed (Spicer et $a l ., 2008)$. In ovine theca cells, the BMPs (2, 4 and 6 tested) inhibited LH-stimulated androstenedione production (Campbell et al., 2006). Consistent with this observation, ewes that were heterozygous for both the Inverdale and Booroola mutations $(\mathrm{I}+\mathrm{B}+)$, tended to have increased expression of CYP17A1, which is expressed exclusively in the theca in ovine ovarian follicles (Logan et al., 2002), in small (1-3 $\mathrm{mm}$ in diameter) follicles (Juengel et al., 2017).

The effects of BMPs on steroid production in granulosa cells is complex. In both sheep and cattle granulosa cells, BMP2, 4, 6, and 7, as well as the combination of BMP15 \& GDF9 strongly suppressed progesterone production when IGF was included in the media (Fabre et al., 2003; Glister et al., 2004; McNatty et al., 2005; Juengel et al., 2006b). A weaker suppression of basal progesterone production was also observed when examined in cattle (Glister et al., 2004) and sheep (Pierre et al., 2004). In sheep, BMP4 (only ligand tested) decreased expression of mRNA and protein for STAR and CYP11A1, likely through inhibiting the actions of SF1 (Pierre et al., 2004). TGFB1 and 2, GDF5 and GDF9 also reduced progesterone production from ovine or bovine granulosa cells (Fabre et al., 2003; Juengel et al., 2004a; Spicer et al., 2006). In bovine granulosa cells, the TGFB1 induced reduction of progesterone production was associated with downregulation of STAR, CYP11A1, and HSD3B1 mRNAs (Zheng et al., 2008). However, various BMPs have also been shown to either increase FSH and IGF1 stimulated oestradiol production (Glister et al., 2004; Campbell et al., 2006; Selvaraju et al., 2013), or have no effect, or suppress oestradiol production, dependent on the dose of both the BMP and the IGF (Campbell et al., 2006). TGFB1 also increased basal oestradiol synthesis and the expression of CYP19A1 and HSD17B1 (Zheng et al., 2009). GDF9 suppressed oestradiol production from bovine granulosa cells collected from both small and large antral follicles (Spicer et al., 2006). Thus overall, BMPs, GDFs and TGFB appear to inhibit progesterone production from granulosa cells, likely through down regulation of proteins important for steroid synthesis. The effects of the superfamily members on oestradiol production is less consistent, with potential for differences observed being related to species, which family member is being examined and dose of growth factor used.

The effects of mutations in BMP15 or BMP1B in ewes, and increased expression of SMAD6, an inhibitory SMAD for the BMP pathway (i.e. the Trio cattle which have a genetic based increase in ovulation rate), on steroid secretion from follicles and cells has also been examined. Granulosa cells from homozygous Booroola animals secreted increased concentrations of oestradiol and theca cells secreted increased concentrations of androstenedione (Campbell et al., 2006), indicative of enhanced oestrogen production. It is important to note that the follicles in homozygous Booroola animals mature at a smaller size than wildtype and thus follicles of similar sizes likely have differing maturation status. However, this difference was at least partially accounted for as smaller diameter follicles were collected from the Booroola animals (Campbell et al., 2006). Expression of CYP19A1 mRNA was increased in small follicles from ewes heterozygous for the Booroola mutation (as well as one copy of the Inverdale mutation). However, whether the Booroola mutation increases or decreases the sensitivity of the receptor to BMPs is unclear, with some studies observing an increased sensitivity (Campbell et al., 2006; Young et al., 2008), and others a decreased sensitivity (Fabre et al., 2003). Potentially further complicating this model is the finding that BMP15 mRNA is decreased in homozygous Booroola ewes (Crawford et al., 2011). In the Trio animals, with overexpression of SMAD6 in cattle follicles (Kamalludin et al., 2018), a similar phenotype to that observed in ewes carrying the Booroola or Inverdale mutation, with ovulation of multiple smaller follicles, is seen (Garcia-Guerra et al., 2018a, b). In the Trio animals, with follicles of similar size, increased oestradiol concentrations in follicular fluid are also observed (Garcia-Guerra et al., 2018b).

In heterozygous Inverdale ewes, overall secretion of oestradiol from all the preovulatory follicles 
is similar to that observed in wild-type ewes. However, the follicles in the Inverdale ewe are smaller with fewer granulosa cells in each follicle, and with more follicles contributing to the overall pool of granulosa cells secreting oestradiol (and inhibin) to influence the hypothalamus and pituitary (Shackell et al., 1993; Juengel et al., 2013a). No differences in concentrations of oestradiol in follicular fluid were noted when comparisons were based on follicular diameter. The secretory capacity of each granulosa cell for oestradiol or inhibin appeared similar between heterozygous Inverdale and wild-type ewes (Shackell et al., 1993).

Further evidence of the role of the BMP family in normal follicular function is provided by the observation that in cattle, alterations in expression of BMP4, BMP6 and BMPR1B occur during the development of ovarian cysts (Diaz et al., 2016). Development of ovarian cysts is known to be related to alterations in apoptosis and steroid production in the ovarian follicle (Ortega et al., 2015).

\section{Effects on responsiveness to FSH and $\mathrm{LH}$}

A key feature of granulosa cells from ewes carrying Inverdale and/or Booroola mutations, thus likely lower BMP15 activity, is an earlier onset of responsiveness to $\mathrm{LH}$. This has been observed when examining the mRNA encoding $L H C G R$ or the ability of the cells to bind and respond to $\mathrm{LH}$, as assessed by cAMP production (McNatty et al., 2009, 2017; Crawford et al., 2011; Juengel et al., 2017). Similarly, in cows carrying a copy of the Trio mutation, which have increased expression of mRNA encoding the inhibitory SMAD6 (Kamalludin et al., 2018), thus postulated reduced BMP signalling, follicles have an earlier responsiveness to $\mathrm{LH}$ with increased expression of the LHR in the granulosa cells (Garcia-Guerra et al., 2018a). Treatment of bovine theca cells with BMPs also reduces LH stimulated androstenedione production, indicative of reduced responsiveness to LH (Glister et $a l ., 2005)$. In contrast, theca cells isolated from small antral follicles collected from homozygous carriers of the Booroola mutation produced more androstenedione when stimulated with low doses of LH (Campbell et al. 2006) compared to non-carriers. However, basal secretion was also increased and thus responsiveness was not greater. Additionally, BMPs inhibited LH stimulated androstenedione production in ovine theca cells (Campbell et al., 2006). Thus, collectively, it appears BMPs inhibit LH responsiveness of follicular cells.

The role of BMPs in regulating FSHR expression is less clear. FSH responsiveness, as measured by mRNA encoding FSHR or the ability of the cells to bind and respond to FSH in general, is not different between control ewes and ewes carrying the Inverdale and/or Booroola mutations (McNatty et al., 2009, 2017; Crawford et al., 2011; Juengel et al., 2017). Similarly, cows carrying the Trio mutation do not have differential expression of FSHR mRNA compared to non-carrier controls (Garcia-Guerra et al., 2018a). However, FSHR mRNA was increased in preantral bovine follicles cultured with hBMP15 or mGDF9 alone, but this effect was lost when follicles were also exposed to FSH (Passos et al., 2013; Vasconcelos et al., 2013). It is also important to note that BMP15 and GDF9 from different species appear to activate different second messenger systems, and thus the source of the BMP15 or GDF9 could affect outcomes (Reader et al., 2011, 2016). Granulosa cells collected from small follicles of homozygous Booroola ewes were more responsive to $\mathrm{FSH}$ when assessed by stimulation of oestradiol production (Campbell et al., 2006). However, it is known that the onset of CYP19A1 mRNA expression and thus aromatase activity occurs at a smaller follicular diameter in ewes carrying the Booroola mutation than their wild-type contemporaries (McNatty et al., 1985; Juengel et al., 2017). Thus the observed difference in oestradiol response is likely related to increased amounts of aromatase.

\section{Using knowledge of local regulation of folliculogenesis to improve advanced breeding programmes}

Ewes with multiple mutations in genes interacting with the TGFB superfamily can have very high ovulation rates $(>10)$, producing similar numbers of embryos as traditional multiple ovulation embryo transfer (MOET) protocols, providing evidence that modulation of this pathway has the potential to form the basis for a new MOET protocol (McNatty et al., 2017). Additionally, these increases in ovulation rate occur without disturbing the normal endocrine patterns of the animal. This is in contrast to what is observed in traditional MOET procedures, which stimulate increased hormonal production from the ovary through elevated FSH concentrations. Therefore reducing the activity of members of the TGFB superfamily potentially will improve oocyte quality and embryo health compared to FSH based protocols (McNatty et al., 2017). In both sheep and cattle, immunisation against either BMP15 or GDF9 can increase ovulation rates, inducing a superovulation type effect in some animals (Juengel et al., 2002, 2004b, 2009), without compromising fertilisation or embryo/fetal development (Juengel et al., 2004b). The challenges with this approach are variable response of the animals to immunisation, both within and between species, resulting in varying efficiencies in neutralisation of bioactivity, coupled with the fact that lack of or very low levels of bioactivity of either GDF9 or BMP15 leads to blockage of ovarian follicular development potentially for months (Juengel et al., 2002, 2011; McNatty et al., 2007). The extracellular region of the BMPR2 is able to block the proliferative activity of GDF9 \& BMP15 combined (Edwards et al., 2008). The extracellular region of the BMPR2 fused with an IgG domain can be produced in vitro (Myllymaa et al., 2010) and might provide a more controlled approach to mimic the neutralising effects of an active immunisation. However, both GDF9 and BMP15 regulate cumulus cell function and have been linked to improved oocyte development when used during in 
vitro oocyte maturation for in vitro production of embryos (reviewed in Russell et al., 2016; Juengel, 2018) and thus reducing the bioactivity too far might decrease embryo quality. However, there is no evidence of reduced embryo quality in ewes with reduced GDF9 or BMP15 bioactivity, or mutations in BMPR1B in vivo (Juengel et al., 2004b, 2013b, 2018; McNatty et al., 2006, 2017), except in heterozygous carriers of the Inverdale mutation undergoing MOET (McNatty et al., 2006).

Ewes heterozygous for the Inverdale mutation, or homozygous for the Booroola mutation have increased responsiveness to a MOET protocol than the non-carrier contemporaries (McNatty et al., 2006). However, ewes heterozygous for an inactivating mutation in GDF9 did not have increased responsiveness to MOET (Pinto et al., 2018). Furthermore, subgroups of animals homozygous for the Booroola mutation have a suppressed responsiveness to FSH-based superovulation procedures potentially through interactions with other, currently unidentified, genetic mutations (Juengel et al., 2013a). Attempts to mimic the increased responsiveness to FSH-based superovulation protocols in Inverdale ewes using immunisation to decrease BMP15 activity have not been successful (Juengel et al., 2011). Additionally, while overall responsiveness to MOET protocols is increased in ewes carrying the Inverdale $(\mathrm{I}+)$ or Booroola $(\mathrm{BB})$ mutation, there are still similar levels of variation in response between ewes as observed in wild-type contemporaries. For instance while overall ovulation rate from superovulated homozygous carriers of the Booroola mutation was $26.3 \pm 1.4$, only $59 \%$ of the animals produced 4 or more embryos. This is comparable with the $51 \%$ of the wild-type contemporaries producing 4 or more embryos (McNatty et al., 2006).

\section{Conclusions and future directions}

While it is clear that locally produced factors are critical for regulation of ovarian function throughout the growth and maturation of the ovarian follicle, there is still much to learn. Key mechanisms by which local factors alter ovarian follicular growth and maturation are through regulation of the rate of cell proliferation and responsiveness to gonadotrophins. Here it is clear that members of the TGFB superfamily, particularly BMP15 and GDF9, are key local regulators of follicular development in ruminants, but other family members are also critical and the relative importance of different family members may vary between species, even between closely related ruminants. The potential to use knowledge regarding the local regulators of follicular development to enhance assisted reproductive technologies or treat reproductive pathologies is also present. However, this requires additional understanding of the actions of the local factors and new, cost-effective technologies to modulate these factors in vivo.

\section{Acknowledgments}

Funding for writing this review was provided by AgResearch's Strategic Science Investment Fund from NZ Ministry of Business, Innovation \& Employment.

\section{References}

An X, Song Y, Hou J, Zhang Y, Chen K, Ma H, Zhao X, Li G, Gao K, Wang S, Cao B, Bai Y. 2017. ChimiR-4110 promotes granulosa cell apoptosis by targeting Sma- and Mad-related protein $2(\operatorname{Smad} 2)$ in the caprine ovary. PLoS One, 12:e0181162. doi: 10.1371/journal.pone.0181162.

Bao B, Garverick HA. 1998. Expression of steroidogenic enzyme and gonadotropin receptor genes in bovine follicles during ovarian follicular waves: a review. J Anim Sci, 76:1903-1921.

Barros VR, Cavalcante AY, Macedo TJ, Barberino RS, Lins TL, Gouveia BB, Menezes VG, Queiroz MA, Araujo VR, Palheta RC, Jr, Leite MC, Matos MH. 2013. Immunolocalization of melatonin and follicle-stimulating hormone receptors in caprine ovaries and their effects during in vitro development of isolated pre-antral follicles. Reprod Domest Anim, 48:1025-1033.

Batista AM, Silva DM, Rego MJ, Silva FL, Silva EC, Beltrao EI, Gomes Filho MA, Wischral A, Guerra MM. 2013. The expression and localization of leptin and its receptor in goat ovarian follicles. Anim Reprod Sci, 141:142-147.

Bezard J, Vigier B, Tran D, Mauleon P, Josso N. 1987. Immunocytochemical study of anti-Mullerian hormone in sheep ovarian follicles during fetal and postnatal development. J Reprod Fertil, 80:509-516.

Braw-Tal R, McNatty KP, Smith P, Heath DA, Hudson NL, Phillips DJ, McLeod BJ, Davis GH. 1993. Ovaries of ewes homozygous for the X-linked Inverdale gene (FecXI) are devoid of secondary and tertiary follicles but contain many abnormal structures. Biol Reprod, 49:895-907.

Braw-Tal R. 1994. Expression of mRNA for follistatin and inhibin/activin subunits during follicular growth and atresia. J Mol Endocrinol, 13:253-264.

Brito IR, Lima IM, Saraiva MV, Silva CM, Magalhaes-Padilha DM, Araujo VR, Barreto Luz V, Barbalho Silva AW, Campello CC, Silva JR, Figueiredo JR. 2012. Expression levels of mRNAencoding PDGF receptors in goat ovaries and the influence of PDGF on the in vitro development of caprine pre-antral follicles. Reprod Domest Anim, 47:695-703.

Buratini J Jr, Pinto MG, Castilho AC, Amorim RL, Giometti IC, Portela VM, Nicola ES, Price CA. 2007. Expression and function of fibroblast growth factor 10 and its receptor, fibroblast growth factor receptor $2 \mathrm{~B}$, in bovine follicles. Biol Reprod, 77:743-750.

Buratini J, Price CA. 2011. Follicular somatic cell factors and follicle development. Reprod Fertil Dev, 23:32-39.

Campbell BK, Souza CJ, Skinner AJ, Webb R, Baird DT. 2006. Enhanced response of granulosa and theca cells from sheep carriers of the FecB mutation in vitro to gonadotropins and bone morphogenic protein-2, -4, and -6. Endocrinology, 147:1608-1620. 
Campbell BK, Hernandez-Medrano J, McNeilly AS, Webb R, Picton HM. 2014. Ovarian function in domestic ruminants: mechanistic and translational aspects. In: Juengel JL, Miyamoto A, Price C, Reynolds LP, Smith MF, Webb R (Ed.). Reproduction in Domestic Ruminants VIII: Proceedings of the Ninth International Symposium on Reproduction in Domestic Ruminants, 2014, Obihiro, Hokkaido, Japan. Ashby-dela-Zouch, UK: Context Products Ltd. pp. 359-373.

Chen H, Liu C, Jiang H, Gao Y, Xu M, Wang J, Liu S, Fu Y, Sun X, Xu J, Zhang J, Dai L. 2017. Regulatory role of miRNA-375 in expression of BMP15/GDF9 receptors and its effect on proliferation and apoptosis of bovine cumulus cells. Cell Physiol Biochem, 41:439-450.

Costa JJ, Passos MJ, Leitao CC, Vasconcelos GL, Saraiva MV, Figueiredo JR, van den Hurk R, Silva JR. 2012. Levels of mRNA for bone morphogenetic proteins, their receptors and SMADs in goat ovarian follicles grown in vivo and in vitro. Reprod Fertil Dev, 24:723-732.

Crawford JL, Heath DA, Reader KL, Quirke LD, Hudson NL, Juengel JL, McNatty KP. 2011. Oocytes in sheep homozygous for a mutation in bone morphogenetic protein receptor $1 \mathrm{~B}$ express lower mRNA levels of bone morphogenetic protein 15 but not growth differentiation factor 9. Reproduction, 142:5361.

Davis GH, McEwan JC, Fennessy PF, Dodds KG, McNatty KP, O WS. 1992. Infertility due to bilateral ovarian hypoplasia in sheep homozygous (FecXI FecXI) for the Inverdale prolificacy gene located on the $\mathrm{X}$ chromosome. Biol Reprod, 46:636-640.

Diaz PU, Hein GJ, Belotti EM, Rodriguez FM, Rey F, Amweg AN, Matiller V, Baravalle ME, Ortega HH, Salvetti NR. 2016. BMP2, 4 and 6 and BMPR1B are altered from early stages of bovine cystic ovarian disease development. Reproduction, 152:333-350.

Driancourt MA, Cahill LP, Bindon BM. 1985. Ovarian follicular populations and preovulatory enlargement in Booroola and control Merino ewes. $J$ Reprod Fertil, 73:93-107.

Edwards SJ, Reader KL, Lun S, Western A, Lawrence S, McNatty KP, Juengel JL. 2008. The cooperative effect of growth and differentiation factor-9 and bone morphogenetic protein (BMP)-15 on granulosa cell function is modulated primarily through BMP receptor II. Endocrinology, 149:1026-1030.

Estienne A, Price CA. 2018. The fibroblast growth factor 8 family in the female reproductive tract. Reproduction, 155:R53-R62.

Fabre S, Pierre A, Pisselet C, Mulsant P, Lecerf F, Pohl J, Monget P, Monniaux D. 2003. The Booroola mutation in sheep is associated with an alteration of the bone morphogenetic protein receptor-IB functionality. $J$ Endocrinol, 177:435-444.

Feary ES, Juengel JL, Smith P, French MC, O'Connell AR, Lawrence SB, Galloway SM, Davis GH, McNatty KP. 2007. Patterns of expression of messenger RNAs encoding GDF9, BMP15, TGFBR1, BMPR1B, and BMPR2 during follicular development and characterization of ovarian follicular populations in ewes carrying the Woodlands FecX2W mutation. Biol Reprod, 77:990-998.

Galloway SM, McNatty KP, Cambridge LM, Laitinen MP, Juengel JL, Jokiranta TS, McLaren RJ, Luiro K, Dodds KG, Montgomery GW, Beattie AE, Davis GH, Ritvos O. 2000. Mutations in an oocyte-derived growth factor gene (BMP15) cause increased ovulation rate and infertility in a dosagesensitive manner. Nat Genet, 25:279-283.

Garcia-Guerra A, Canavessi AMO, Monteiro PLJ, Jr., Mezera MA, Sartori R, Kirkpatrick BW, Wiltbank MC. 2018a. Trio, a novel bovine high fecundity allele: III. Acquisition of dominance and ovulatory capacity at a smaller follicle size. Biol Reprod, 98:350-365.

Garcia-Guerra A, Kamalludin MH, Kirkpatrick BW, Wiltbank MC. 2018b. Trio a novel bovine highfecundity allele: II. Hormonal profile and follicular dynamics underlying the high ovulation rate. Biol Reprod, 98:335-349.

Gilchrist RB, Morrissey MP, Ritter LJ, Armstrong DT. 2003. Comparison of oocyte factors and transforming growth factor-beta in the regulation of DNA synthesis in bovine granulosa cells. Mol Cell Endocrinol, 201:87-95.

Gilchrist RB, Ritter LJ, Myllymaa S, Kaivo-Oja N, Dragovic RA, Hickey TE, Ritvos O, Mottershead DG. 2006. Molecular basis of oocyte-paracrine signalling that promotes granulosa cell proliferation. $J$ Cell Sci, 119:3811-3821.

Glister C, Kemp CF, Knight PG. 2004. Bone morphogenetic protein (BMP) ligands and receptors in bovine ovarian follicle cells: actions of BMP-4, -6 and 7 on granulosa cells and differential modulation of Smad-1 phosphorylation by follistatin. Reproduction, 127:239-254.

Glister C, Richards SL, Knight PG. 2005. Bone morphogenetic proteins (BMP) $-4,-6$, and -7 potently suppress basal and luteinizing hormone-induced androgen production by bovine theca interna cells in primary culture: could ovarian hyperandrogenic dysfunction be caused by a defect in thecal BMP signaling? Endocrinology, 146:1883-1892.

Glister C, Satchell L, Knight PG. 2010. Changes in expression of bone morphogenetic proteins (BMPs), their receptors and inhibin co-receptor betaglycan during bovine antral follicle development: inhibin can antagonize the suppressive effect of BMPs on thecal androgen production. Reproduction, 140:699-712.

Hao L, Wang D, Zhang G, Ma W, Li C, Jiang H. 2014. Vascular endothelial growth factor expression correlated with microvessel density in the antral follicle of sheep. Livest Sci, 165:212.

Hussein TS, Froiland DA, Amato F, Thompson JG, Gilchrist RB. 2005. Oocytes prevent cumulus cell apoptosis by maintaining a morphogenic paracrine gradient of bone morphogenetic proteins. $J$ Cell Sci, 118:5257-5268.

Juengel JL, Hudson NL, Heath DA, Smith P, Reader KL, Lawrence SB, O'Connell AR, Laitinen MP, Cranfield M, Groome NP, Ritvos O, McNatty KP. 2002. Growth differentiation factor 9 and bone 
morphogenetic protein 15 are essential for ovarian follicular development in sheep. Biol Reprod, 67:17771789.

Juengel JL, Bibby AH, Reader KL, Lun S, Quirke LD, Haydon LJ, McNatty KP. 2004a. The role of transforming growth factor-beta (TGF-beta) during ovarian follicular development in sheep. Reprod Biol Endocrinol, 2:78. doi: 10.1186/1477-7827-2-78

Juengel JL, Hudson NL, Whiting L, McNatty KP. 2004b. Effects of immunization against bone morphogenetic protein 15 and growth differentiation factor 9 on ovulation rate, fertilization, and pregnancy in ewes. Biol Reprod, 70:557-561.

Juengel JL, Heath DA, Quirke LD, McNatty KP. 2006a. Oestrogen receptor alpha and beta, androgen receptor and progesterone receptor $\mathrm{mRNA}$ and protein localisation within the developing ovary and in small growing follicles of sheep. Reproduction, 131:81-92.

Juengel JL, Reader KL, Bibby AH, Lun S, Ross I, Haydon LJ, McNatty KP. 2006b. The role of bone morphogenetic proteins 2, 4, 6 and 7 during ovarian follicular development in sheep: contrast to rat. Reproduction, 131:501-513.

Juengel JL, Hudson NL, Berg M, Hamel K, Smith P, Lawrence SB, Whiting L, McNatty KP. 2009. Effects of active immunization against growth differentiation factor 9 and/or bone morphogenetic protein 15 on ovarian function in cattle. Reproduction, 138:107-114.

Juengel JL, Quirke LD, Lun S, Heath DA, Johnstone PD, McNatty KP. 2011. Effects of immunizing ewes against bone morphogenetic protein 15 on their responses to exogenous gonadotrophins to induce multiple ovulations. Reproduction, 142:565-572.

Juengel JL, Davis GH, McNatty KP. 2013a. Using sheep lines with mutations in single genes to better understand ovarian function. Reproduction, 146:R111123.

Juengel JL, Proctor LE, Wearne K, Olliver D, Hudson NL, Jensen D, Davis GH, Johnstone PD, McNatty KP. 2013b. Effects of immunization against androstenedione or bone morphogenetic protein 15 (BMP15) on reproductive performance in sheep. J Anim Sci, 91:5946-5953.

Juengel JL, Smith P. 2014. Formation of ovarian foliclles in ruminants. In: Juengel JL, Miyamoto A, Price CA, Reynolds LP, Smith MF, Webb R (Ed.). Reproduction in domestic ruminants VIII: Proceedings of the Ninth International Symposium on Reproduction in Domestic Ruminants, Obihiro, 2014, Hokkaido, Japan. Ashby-de-la-Zouch, UK: Context Products Ltd. pp. 277-293.

Juengel JL, French MC, Quirke LD, Kauff A, Smith GW, Johnstone PD. 2017. Differential expression of CART in ewes with differing ovulation rates. Reproduction, 153:471-479.

Juengel JL. 2018. How the quest to improve sheep reproduction provided insight into oocyte control of follicular development. $J R$ Soc $N Z$, 48:143-163.

Kamalludin MH, Garcia-Guerra A, Wiltbank MC, Kirkpatrick BW. 2018. Trio, a novel high fecundity allele: I. Transcriptome analysis of granulosa cells from carriers and noncarriers of a major gene for bovine ovulation rate. Biol Reprod, 98:323-334.

Kayamori T, Kosaka N, Miyamoto A, Shimizu T. 2009. The differential pathways of bone morphogenetic protein (BMP)-4 and -7 in the suppression of the bovine granulosa cell apoptosis. Mol Cell Biochem, 323:161168.

Knight PG, Satchell L, Glister C. 2012. Intra-ovarian roles of activins and inhibins. Mol Cell Endocrinol, 359:53-65.

Knight PG, Glister C. 2014. Theca cells and the regulation of ovarian androgen production. In: Juengel JL, Miyamoto A, Price C, Reynolds LP, Smith MF, Webb R (Ed.). Reproduction in Domestic Ruminants VIII: Proceedings of the Ninth International Symposium on Reproduction in Domestic Ruminants, Obihiro, 2014, Hokkaido, Japan. Ashby-de-la-Zouch, UK: Context Products Ltd. pp. 295-310.

Kobayashi Y, Jimenez-Krassel F, Li Q, Yao J, Huang R, Ireland JJ, Coussens PM, Smith GW. 2004. Evidence that cocaine- and amphetamineregulated transcript is a novel intraovarian regulator of follicular atresia. Endocrinology, 145:5373-5383.

Leeuwenberg BR, Hurst PR, McNatty KP. 1995. Expression of IGF-I mRNA in the ovine ovary. $J \mathrm{Mol}$ Endocrinol, 15:251-258.

Lima IM, Brito IR, Rossetto R, Duarte AB, Rodrigues GQ, Saraiva MV, Costa JJ, Donato MA, Peixoto CA, Silva JR, de Figueiredo JR, Rodrigues AP. 2012. BMPRIB and BMPRII mRNA expression levels in goat ovarian follicles and the in vitro effects of BMP-15 on preantral follicle development. Cell Tissue Res, 348:225-238.

Logan KA, Juengel JL, McNatty KP. 2002. Onset of steroidogenic enzyme gene expression during ovarian follicular development in sheep. Biol Reprod, 66:906-916.

Logan KA, McNatty KP, Juengel JL. 2003. Expression of wilms' tumor gene and protein localization during ovarian formation and follicular development in sheep. Biol Reprod, 68:635-643.

Lundy T, Smith P, O'Connell A, Hudson NL, McNatty KP. 1999. Populations of granulosa cells in small follicles of the sheep ovary. J Reprod Fertil, 115:251-262.

Matsuda F, Inoue N, Manabe N, Ohkura S. 2012. Follicular growth and atresia in mammalian ovaries: regulation by survival and death of granulosa cells. $J$ Reprod Dev, 58:44-50.

McNatty KP, Henderson KM, Lun S, Heath DA, Ball K, Hudson NL, Fannin J, Gibb M, Kieboom LE, Smith P. 1985. Ovarian activity in Booroola X Romney ewes which have a major gene influencing their ovulation rate. J Reprod Fertil, 73:109-120.

McNatty KP, Heath DA, Hudson N, Clarke IJ. 1990. Effect of long-term hypophysectomy on ovarian follicle populations and gonadotrophin-induced adenosine cyclic 3',5'-monophosphate output by follicles from Booroola ewes with or without the $\mathrm{F}$ gene. $J$ Reprod Fertil, 90:515-522.

McNatty KP, Juengel JL, Reader KL, Lun S, Myllymaa S, Lawrence SB, Western A, Meerasahib MF, Mottershead DG, Groome NP, Ritvos O, Laitinen MP. 2005. Bone morphogenetic protein 15 
and growth differentiation factor 9 co-operate to regulate granulosa cell function in ruminants. Reproduction, 129:481-487.

McNatty KP, Hudson N, Smith P, Juengel JL. 2006. The effects of superovulating sheep with mutations in either the activin-like kinase (Alk6) or bone morphogenetic protein (BMP15) genes on ovulation rate and embryo production. J Reprod Dev, 52:S39-S43.

McNatty KP, Hudson NL, Whiting L, Reader KL, Lun S, Western A, Heath DA, Smith P, Moore LG, Juengel JL. 2007. The effects of immunizing sheep with different BMP15 or GDF9 peptide sequences on ovarian follicular activity and ovulation rate. Biol Reprod, 76:552-560.

McNatty KP, Heath DA, Hudson NL, Lun S, Juengel JL, Moore LG. 2009. Gonadotrophin-responsiveness of granulosa cells from bone morphogenetic protein 15 heterozygous mutant sheep. Reproduction, 138:545-551.

McNatty KP, Heath DA, Clark Z, Reader K, Juengel JL, Pitman JL. 2017. Ovarian characteristics in sheep with multiple fecundity genes. Reproduction, 153:233240.

Mihm M, Bleach EC. 2003. Endocrine regulation of ovarian antral follicle development in cattle. Anim Reprod Sci, 78:217-237.

Monniaux D, Clement F, Dalbies-Tran R, Estienne A, Fabre S, Mansanet C, Monget P. 2014. The ovarian reserve of primordial follicles and the dynamic reserve of antral growing follicles: what is the link? Biol Reprod, 90:85. doi: 10.1095/biolreprod.113.117077.

Myllymaa S, Pasternack A, Mottershead DG, Poutanen M, Pulkki MM, Pelliniemi LJ, Ritvos O, Laitinen MP. 2010. Inhibition of oocyte growth factors in vivo modulates ovarian folliculogenesis in neonatal and immature mice. Reproduction, 139:587-598.

Nicol L, Bishop SC, Pong-Wong R, Bendixen C, Holm LE, Rhind SM, McNeilly AS. 2009. Homozygosity for a single base-pair mutation in the oocyte-specific GDF9 gene results in sterility in Thoka sheep. Reproduction, 138:921-933.

Nilsson EE, Doraiswamy V, Skinner MK. 2003. Transforming growth factor-beta isoform expression during bovine ovarian antral follicle development. $\mathrm{Mol}$ Reprod Dev, 66:237-246.

Ortega HH, Marelli BE, Rey F, Amweg AN, Diaz PU, Stangaferro ML, Salvetti NR. 2015. Molecular aspects of bovine cystic ovarian disease pathogenesis. Reproduction, 149:R251-264.

Pankhurst MW. 2017. A putative role for antiMullerian hormone (AMH) in optimising ovarian reserve expenditure. $J$ Endocrinol, 233:R1-R13.

Passos MJ, Vasconcelos GL, Silva AW, Brito IR, Saraiva MV, Magalhaes DM, Costa JJ, Donato MA, Ribeiro RP, Cunha EV, Peixoto CA, Campello CC, Figueiredo JR, van den Hurk R, Silva JR. 2013. Accelerated growth of bovine preantral follicles in vitro after stimulation with both FSH and BMP-15 is accompanied by ultrastructural changes and increased atresia. Theriogenology, 79:1269-1277.

Pierre A, Pisselet C, Dupont J, Mandon-Pepin B, Monniaux D, Monget P, Fabre S. 2004. Molecular basis of bone morphogenetic protein- 4 inhibitory action on progesterone secretion by ovine granulosa cells. $J$ Mol Endocrinol, 33:805-817.

Pinto PHN, Balaro MFA, Souza-Fabjan JMG, Ribeiro LDS, Braganca GM, Leite CR, Arashiro EKN, de Moraes Silva K, Da Fonseca JF, Brandao FZ. 2018. Anti-Mullerian hormone and antral follicle count are more effective for selecting ewes with good potential for in vivo embryo production than the presence of $\mathrm{FecG}(\mathrm{E})$ mutation or eCG pre-selection tests. Theriogenology, 113:146-152.

Pohler KG, Geary TW, Atkins JA, Perry GA, Jinks EM, Smith MF. 2012. Follicular determinants of pregnancy establishment and maintenance. Cell Tissue Res, 349:649-664.

Price CA. 2016. Mechanisms of fibroblast growth factor signaling in the ovarian follicle. $J$ Endocrinol, 228:R31-43.

Reader KL, Heath DA, Lun S, McIntosh CJ, Western AH, Littlejohn RP, McNatty KP, Juengel JL. 2011. Signalling pathways involved in the cooperative effects of ovine and murine GDF9+BMP15stimulated thymidine uptake by rat granulosa cells. Reproduction, 142:123-131.

Reader KL, Mottershead DG, Martin GA, Gilchrist RB, Heath DA, McNatty KP, Juengel JL. 2016. Signalling pathways involved in the synergistic effects of human growth differentiation factor 9 and bone morphogenetic protein 15. Reprod Fertil Dev, 28:491498.

Rodrigues GQ, Bertoldo MJ, Brito IR, Silva CM, Sales AD, Castro SV, Duffard N, Locatelli Y, Mermillod P, Lobo CH, Campello CC, Rodrigues AP, Freitas VJ, Figueiredo JR. 2014. Relative mRNA expression and immunolocalization for transforming growth factor-beta (TGF-beta) and their effect on in vitro development of caprine preantral follicles. In Vitro Cell Dev Biol Anim, 50:688-699.

Russell DL, Gilchrist RB, Brown HM, Thompson JG. 2016. Bidirectional communication between cumulus cells and the oocyte: old hands and new players? Theriogenology, 86:62-68.

Saraiva MV, Celestino JJ, Araujo VR, Chaves RN, Almeida AP, Lima-Verde IB, Duarte AB, Silva GM, Martins FS, Bruno JB, Matos MH, Campello CC, Silva JR, Figueiredo JR. 2011. Expression of folliclestimulating hormone receptor (FSHR) in goat ovarian follicles and the impact of sequential culture medium on in vitro development of caprine preantral follicles. Zygote, 19:205-214.

Scaramuzzi RJ, Baird DT, Campbell BK, Driancourt MA, Dupont J, Fortune JE, Gilchrist RB, Martin GB, McNatty KP, McNeilly AS, Monget P, Monniaux D, Vinoles C, Webb R. 2011. Regulation of folliculogenesis and the determination of ovulation rate in ruminants. Reprod Fertil Dev, 23:444-467.

Selvaraju S, Folger JK, Gupta PS, Ireland JJ, Smith GW. 2013. Stage-specific expression and effect of bone morphogenetic protein 2 on bovine granulosa cell estradiol production: regulation by cocaine and amphetamine regulated transcript. Domest Anim Endocrinol, 44:115-120.

Shackell GH, Hudson NL, Heath DA, Lun S, Shaw 
L, Condell L, Blay LR, McNatty KP. 1993. Plasma gonadotropin concentrations and ovarian characteristics in Inverdale ewes that are heterozygous for a major gene $(\mathrm{FecX} 1)$ on the $\mathrm{X}$ chromosome that influences ovulation rate. Biol Reprod, 48:1150-1156.

Shimizu T, Kayamori T, Murayama C, Miyamoto A. 2012. Bone morphogenetic protein (BMP)-4 and BMP7 suppress granulosa cell apoptosis via different pathways: BMP-4 via PI3K/PDK-1/Akt and BMP-7 via PI3K/PDK-1/PKC. Biochem Biophys Res Commun, 417:869-873.

Shimizu T. 2016. Molecular and cellular mechanisms for the regulation of ovarian follicular function in cows. J Reprod Dev, 62:323-329.

Silva JR, van den Hurk R, Figueiredo JR. 2016. Ovarian follicle development in vitro and oocyte competence: advances and challenges for farm animals. Domest Anim Endocrinol, 55:123-135.

Skinner MK, Keski-Oja J, Osteen KG, Moses HL. 1987. Ovarian thecal cells produce transforming growth factor-beta which can regulate granulosa cell growth. Endocrinology, 121:786-792.

Smith PR. 2012. Development of the Rete Ovarii in the Sheep Ovary. Dunedin, New Zealand: Department of Anatomy, University of Otago. Thesis (Master of Science).

Souza CJ, Campbell BK, McNeilly AS, Baird DT. 2002. Effect of bone morphogenetic protein 2 (BMP2) on oestradiol and inhibin A production by sheep granulosa cells, and localization of BMP receptors in the ovary by immunohistochemistry. Reproduction, 123:363-369.

Spicer LJ, Aad PY, Allen D, Mazerbourg S, Hsueh AJ. 2006. Growth differentiation factor-9 has divergent effects on proliferation and steroidogenesis of bovine granulosa cells. J Endocrinol, 189:329-339.

Spicer LJ, Aad PY, Allen DT, Mazerbourg S, Payne AH, Hsueh AJ. 2008. Growth differentiation factor 9 (GDF9) stimulates proliferation and inhibits steroidogenesis by bovine theca cells: influence of follicle size on responses to GDF9. Biol Reprod, 78:243-253.

Tisdall DJ, Hudson N, Smith P, McNatty KP. 1994. Localization of ovine follistatin and alpha and beta A inhibin mRNA in the sheep ovary during the oestrous cycle. J Mol Endocrinol, 12:181-193.
Tisdall DJ, Watanabe K, Hudson NL, Smith P, McNatty KP. 1995. FSH receptor gene expression during ovarian follicle development in sheep. $J \mathrm{Mol}$ Endocrinol, 15:273-281.

Tisdall DJ, Quirke LD, Smith P, McNatty KP. 1997. Expression of the ovine stem cell factor gene during folliculogenesis in late fetal and adult ovaries. $J \mathrm{Mol}$ Endocrinol, 18:127-135.

Vasconcelos GL, Saraiva MV, Costa JJ, Passos MJ, Silva AW, Rossi RO, Portela AM, Duarte AB, Magalhaes-Padilha DM, Campelo CC, Figueiredo JR, van den Hurk R, Silva JR. 2013. Effects of growth differentiation factor-9 and FSH on in vitro development, viability and mRNA expression in bovine preantral follicles. Reprod Fertil Dev, 25:1194-1203.

Wandji SA, Pelletier G, Sirard MA. 1992. Ontogeny and cellular localization of 125I-labeled basic fibroblast growth factor and 125I-labeled epidermal growth factor binding sites in ovaries from bovine fetuses and neonatal calves. Biol Reprod, 47:807-813.

Xu Z, Garverick HA, Smith GW, Smith MF, Hamilton SA, Youngquist RS. 1995. Expression of follicle-stimulating hormone and luteinizing hormone receptor messenger ribonucleic acids in bovine follicles during the first follicular wave. Biol Reprod, 53:951957.

Young JM, Juengel JL, Dodds KG, Laird M, Dearden PK, McNeilly AS, McNatty KP, Wilson T. 2008. The activin receptor-like kinase 6 Booroola mutation enhances suppressive effects of bone morphogenetic protein 2 (BMP2), BMP4, BMP6 and growth and differentiation factor-9 on FSH release from ovine primary pituitary cell cultures. $J$ Endocrinol, 196:251-261.

Young JM, McNeilly AS. 2010. Theca: the forgotten cell of the ovarian follicle. Reproduction, 140:489-504.

Zheng X, Price CA, Tremblay Y, Lussier JG, Carriere PD. 2008. Role of transforming growth factor-betal in gene expression and activity of estradiol and progesterone-generating enzymes in FSHstimulated bovine granulosa cells. Reproduction, 136:447-457.

Zheng X, Boerboom D, Carriere PD. 2009. Transforming growth factor-betal inhibits luteinization and promotes apoptosis in bovine granulosa cells. Reproduction, 137:969-977. 